УДК 81-119/801.732

\title{
BEYOND FORECASTING AND PREDICTION: THE ROLE OF PHANTASMAGORICAL MEMORY IN IMAGINING THE FUTURE
}

\author{
FAROUK Y. SEIF \\ professor emeritus \\ Antioch University Seattle, Washington, USA \\ fseif@antioch.edu
}

Introduction. Forecasting and predication are influenced by the conventional perception of a reality that has been engulfed by a reaction to austerity and scarcity. Forecasting and linear projection toward the future are problem-solving trajectories that aim at maintaining the status quo. The future is inventable, not inevitable. A desired future cannot be achieved through forecasting and prediction, whether in dystopian fiction or utopian fancy, but can be accomplished through an imaginative future memory and by design. Memory is a phantasmagorical phenomenon, where present reality is constructed by past memory, it can also be transformed by future memory. Future memory requires a shift from being trapped by the gravity of the present to the weightless imaginary future and the freedom of toying with the real. Past memory is recalled to augment strategies for solving current problems, but future memory is imagined to explore design alternatives. Whereas memory of the past becomes our familiar path to forecasting the future, memory of the future provides a meaningful way to access a wide range of unfamiliar options for imagining a desired future.

Purpose. The paper aims at explaining the possible ways of interpreting the language of future as semiology, which can be located within the larger scope of semiotics. Under this larger scope, there are three major semiotic systems: linguistics, kinesics, and objects.

Methods. In cognitive semiotic perspective the paper highlights the methods of interpreting the semiological concept of future in literary text focusing on psychological and sociological data.

Results. Going faster and acquiring material, physical things are considered winning the game of forecasting and projection. It is clear that postmodernity has been superseded by transmodernity. The core value of transmodernity, which embodies many integrative qualities and undissolved differences, emphasizes transparency between pre-modern, modern, and postmodern realities. Not only does transmodernity discard modernity's insistence on autonomy and absoluteness, it also transcends modernism and postmodernity's inclination toward dualistic rationality and an either-or position. A desired future in the transmodern world can be created through phantasmagorical memory and communicated by the notating and scoring process. Such future possibilities are emergent outcomes of the design process that teleologically reveals unlimited options.

Conclusion. Notating the imagination of phantasmagorical memory transforms the status quo into a visceral experience of a desirable future in our transmodern world. This is the way we can transform the present reality into a desired future reality. Without such memory, it would be difficult to avoid the despair about the status quo and to go beyond utopianism and dystopianism. To imagine the future is to transform absoluteness and to participate in a process that seeks meaningful change. Imagining a desired future in the transmodern world is essential for rejuvenating cultural practices and renewing natural environments. And notating imagination - the unseen forces behind physical manifestations - reveals an integrated consciousness that highlights the reciprocal relationship between cultural ethos and environmental ethics.

Keywords: design, future, imagination, memory, notation, phantasmagoria. 
Farouk Y. Seif. Beyond forecasting and prediction: the role of phantasmagorical memory in imagining the future

\section{МІЖ ПРОГОНОЗУВАННЯМ I ПЕРЕДБАЧЕННЯМ: РОЛЬ ФАНТАСМАГОРИЧНОЇ ПАМ'ЯТІ В УЯВЛЕННІ ПРО МАЙБУТНЕ}

FAROUK Y. SEIF

доктор філософії у філології, професор

Антіохійський університет у Сіетлі, Вашингтон, США

fseif@antioch.edu

У статті, що виконана в річищі когнітивно-семіотичного підходу, запропоновано способи інтерпретації мови майбутнього у фікціональних текстах з урахуванням канонів модернізму, постмодернізму й трансмодернізму. Автор зосереджує увагу на вивченні пам'яті як фантасмагоричного феномену, у якому реальність теперішнього конструюється на основі пам'яті минулого і може бути трансформована пам'яттю майбутнього.

Аналізуючи зміст і семантичну структуру понять прогнозування і попередження, автор доводить, що бажане майбутне в трансмодерному світі може моделюватися саме завдяки можливостям фантасмагоричної пам'яті. Прогнозування і попередження мають вплив конвенціональної перцепції реальності, яка поглинула в річищі суворості і дефіциту. Прогнозування й лінійна проекція на майбутнє постають вирішальними траєкторіями, які спрямовані на утримання певного статусу кво. Майбутнє можна передбачити, але не минути. Бажане майбутнє не досягти завдяки прогнозуванню чи попередженню, адже його можна змоделювати. Майбутня пам'ять витримує зсув від гравітаційної пастки теперішнього до невагомої уявності майбутнього і незалежної гри з реальністю. У той час, коли пам'ять минулого слугує відомою стежкою до передбачення минулого, пам'ять майбутнього уможливлює доступ до широкого кола невідомих опцій для уявлення бажаного майбутнього.

Ураховуючи ці особливості пам'яті, минулої, теперішньої і майбутньої, у статті обгрунтовано можливі шляхи розуміння й інтерпретації мови майбутнього (у фікціональних текстах модернізму, постмодернізму й трансмодернізму) як великого корпусу семіотики, що охоплює три основні семіотичні системи: лінгвістику, кінетику й фізичні об'єкти. Фізичні об’єкти виконують домінантну роль у прогнозуванні й попередженні тієї чи тієї реальності. Досвідна реальність базується на власне реальності й уявленнях про цю реальність. Освоєння реальності, по-перше, починається 3 моменту усвідомлення людським розумом суті об'єктів реальності, а по-друге, крізь призму дії знаків, коли уявні об'єкти стають реальними речами. Без дії знаків не буде об'єктів, без об'єктів не буде усвідомлення світу речей, а без дизайну ні об'єкт, ні предмет не матимуть значення. Уявлення бажаного майбутнього в трансмодерному світі є звичайним для оновлення культурологічного досвіду й реінновації природного середовища. Фіксована уява - прихована сила, що криється за фізичною маніфестацією - розкриває інтегровану свідомість, яка висвітлює взаємні відносини між культурним етосом й екологічною етикою.

Ключові слова: дизайн, майбутнє, уявлення, пам'ять, фантасмагорія.

\section{The Limits of Forecasting and Prediction}

Contemporary societies seem to have become addicted to linear projection and forecasting through which glitzy superstructures and gigantic developments have become the driving competitive goal that ultimately leads to the commodification of the future. We live in a double-bind epoch: Either we are so reliant on analytical thinking that we overlook the significance of the realm of imagination, or we are so infatuated with fantasy that we rush nostalgically to a particular form or shape of utopian future. Our absolute limits seem to be the consequence of our avoidance of reframing the problems we encounter in the present situation, which have encouraged dependency on projection from the familiar present and predicting the unfamiliar future. These absolute limits have led to numerous world conflicts, economic austerity, and devastating environmental conditions. Sequential equations and linear projections into the future have merely repeated the problems of the past and have even led the world to the brink of extinction. 
Generally, the aim of projection and forecasting is to make a minor alteration, or adjustment, of past and present conditions; the trajectory itself falls short from making a significant change. Undoubtedly, change can be triggered by different causes: a cosmic event or act of God; necessity or need predetermined by universal law; chance, an accidental event, an unintended act, luck, or the flip of a coin; chaos and disorder as a result of systems bifurcation and randomness; evolution and genetic reconstruction; or intentional design set forth by humans as agents of change (Seif, 2005). Other than intervention by design, there is little or no interference by human beings to handle these causes except by projection and forecasting based on the known past and familiar present. This is why it is through projection and forecasting augmented by problem-solving strategy that humans habitually mitigate changes imposed on them by other causes.

\section{The Fallacy of Dystopian Pessimism and Utopian Optimism}

The projection from the past and present toward the future may have encouraged a negative perception of what lies ahead, as best exemplified in Aldous Huxley's 1932 dystopian novel, Brave New World (Huxley, 1932); John Leslie's 1996 pessimistic book, The End of the World (Leslie, 1996); and Godfrey Reggio's 1982 devastating film, Koyaanisqatsi: Life Out of Balance (Koyaanisqatsi: Life Out of Balance) - to name just a few. Clearly, this gloomy art and literature is based on projections of the past and present, and forecasts of the future. Our inability to imagine and communicate new possibilities is often compromised or obstructed by forecasting and prediction.

Whether the result is doleful pessimism or overzealous optimism, predicating the future is a mere fiction of economic and social biases and political manipulations, constructed to stabilize that which is already in existence. In fact, conservative forecasting and predication are influenced by a reactionary response to the conventional perception of a reality that has been engulfed by austerity and scarcity.

Those who claim to dream of a utopian future through their narrative apparatus often fall too short. Utopian texts and dystopian science fiction seem to be either trapped in a particular form of the future or, in a Kantian sense, be involved in reproductive image-formation that represents an extension of the past and the present. Utopian and science fiction writers acknowledge that their work seems to be mere collages of bits and pieces of current experience, which are hostages to the common mode of thinking and doing. As Fredric Jameson (2005) argues, the most characteristic science fiction does not attempt to imagine a genuine future of our social system. Rather, the simulated futures of science fiction serve the different function of swapping our present into the determinate past of something imminent.

Futures constructed in the science fiction genre are not intended as genuine possibilities. The vocation of science fiction "is over and over again to demonstrate and to dramatize our incapacity to imagine the future, to body forth, through apparently full representations which prove on closer inspection to be structurally and constitutively impoverished" (Jameson, 2005, p. 288). The consequence of our inability to reframe problems, and rely on left-brain dominance, has encouraged dependency on forecasting from the familiar and predicting the future through fiction. Whether inciting pessimism or igniting optimism, prediction has triggered exaggerated expectations and numerous intractable conflicts in our world. By relying on science fiction, prediction has encouraged a bleak attitude about time to come. Likewise, by merely aiming at solving current problems, forecasting is marginally different from the present.

\section{Other than Solving Problems of the Present: Imagining the Future by Design}

Forecasting and predicting are commonly used for problem-solving strategies and cause-and-effect models. Forecasting the future is a mere problem-solving trajectory that aims at fixing what is broken, thereby maintaining the status quo. Granted, forecasts and predictions are effective in mechanical systems and problem-solving strategies; however, they are limited in capturing the infinite imaginative possibilities for renewing social systems. These models and methods lead to minor changes or tweaks that are described by systems theorists as a "first order of change" that fixes what already exists, whereas meaningful change is a "second order of change" that brings something new into being. In exploring 
humans' relation to a desired future, the use of the term 'solution' is confusing. In social systems, there are only "ill-defined" (Cross, 2011) or "wicked problems" (Rittel \& Webber, 1973), not welldefined or tamed problems, which are appropriate for mechanistic strategies.

What is needed in imagining the future is a creative reframing of challenges, which are more often viewed as problems to be solved. The so-called "design solution" to social or cultural problems is an oxymoron. Designing a solution implies that we have a problem. To design a solution, we must define the problem, and to define the problem requires staying within the context of existing boundaries. The strategy - defining problems and coming up with solutions - keeps on producing more problems, or repeating past, nonsensical actions.

Defining a problem based on limited observation of autonomous parts, and relying on existing patterns of thought without being aware of the whole, is like encountering and interpreting a strange object in total darkness! Forecasting and predicting are routine strategies for solving problems, which are well-defined, whereas imagining the future is based on the design approach that deals with illdefined social problems. Labeling design as focusing mainly on problem solving or discovering facts about an observed phenomenon is misleading. If we have to use the term 'solution', then we can appropriately consider designers of the future as solution-focused, not problem-focused agents.

Solving problems is sometimes a necessary first step. Metaphorically, it is the first aid to stop the bleeding, but it does not lead to a long-term healthy way of living. Occasionally, a problemsolving strategy is a good immediate reaction, but it is not an ultimate response. Simultaneously handling problem-solving strategy and design approach may seem like a contradiction. Not quite. It is a paradoxical challenge. Yet, paradoxical challenges are often erroneously perceived as problems. Paradoxes are often perceived as problematic dualisms that must be fixed to favor one pole in a tensional pair over the other (Seif, 2014). But whenever paradoxes are perceived as problems, they can never be solved or dissolved. Rather, sooner or later, apparent solutions are discovered to be illusions, leading to ever-more-tangled problems.

How does paradoxical thinking relate to imagining the future? Imagination demands paradoxical thinking, which is the most significant skill needed in designing a desired future. Paradoxical thinking goes beyond an either/or mindset into a both/and posture and is reflective, transparent, and integrative (Gebser, 1949), all of which undoubtedly requires perseverance and resilience. One of the most astonishing aspects of imagining a desired future is that paradoxical thinking goes against what is expected as common sense into unexpected uncommon sense. That is, common sense is certainly expected in solving problems, whereas uncommon sense is needed for persevering through the paradox of being-in-the-world, yet being divorced from the current situation. There is a need to go beyond what we are conventionally able to predict into what we are imaginatively capable of creating.

\section{Consciousness and Imagination}

Charles S. Peirce says, "An imagination is an affection of consciousness" (CP 2.148); and according to Jean-Paul Sartre (1948), imagination is an essential, transcendental condition of consciousness. Therefore, consciousness would not exist or evolve without imagination, as much as imagination would not occur without consciousness. Imagination incites human beings to shift from common to uncommon sense, to play across boundaries of the existing known reality. All of this brings us to Peirce's concept of "pure play of musement" as a moderate indulgence of recreation (CP 6.458), where it is possible for the real and imaginary worlds to interact. For what defines the imaginary world and the world of the real is our attitude of consciousness (Sartre, 1948). Peirce also tells us that the universe is perfused with signs that transcend the physical world into an imaginary world; this may explain why Peirce declares that "the highest grade of reality is only reached by signs" (CP 8.327), where signs of the real and the imaginary are intertwined.

\footnotetext{
${ }^{1}$ Notating imagination does not rely on language as such. Its theoretical foundation suggests that thoughts occur through images, where images come before words. Imaginative thoughts seem to sit around in some noetic space, a sort of subliminal zone, waiting to be linguistified into being through the design conceptualization and sign process (Seif, 1999).
} 
Giambattista Vico emphasizes the creative power of human beings to transform reality when he introduces fantasia (imagination), the human capacity to ingegno (imagine) anything desirable, and the capacity to convert imaginative thoughts and novel ideas through signs into works of art and innovations in design. According to Vico, this imaginary world is a basic human faculty, not only in the understanding of reality and what is being understood, but also in the re-creation and transformation of reality beyond mere fixing what is broken or maintaining that which already exists through problem-solving strategies. Granted, problem solving can be creative, but it is not necessarily an imaginative approach.

Fantasia is quite different from fiction. Fiction relies on visualization and is based on some facts that exist in real life, and at the same time are untrue, but likely to be true. It is often difficult to determine the boundary between fact and fiction (Danesi, 2007; Propp, 1928). Fantasia relies on imagination, and at first seems conceptually impossible, but as Jacques Derrida (Danesi, 2007) argues, impossibility is what happens outside our anticipation of possibility. Both possibility and impossibility reside in our consciousness and ways of imaginative thinking.

Visualization relies on the five senses: seeing, hearing, smelling, tasting, touching. But because imaginative thoughts are irreducible to sensation, they are not accessible through the senses. If I remember an event in my past life, Jean-Paul Sartre (1948, p. 263) says, "I do not imagine it, I recall it," or visualize it. Of course, consciousness must be able to visualize in order to be able to imagine; to bring images into consciousness we must visualize them. Consciousness has a number of ways of "surpassing the real in order to make a world of it"; and this surpassing "can and should happen at first by affectivity or by action" (Sartre, 1948, p. 268).

Our senses alone are not our source of imagination (Barfield, 1977; Grudin, 1990). Through the use of the five senses (sight, smell, hearing, taste, and touch), memory of past experiences is usually recalled to the present, but memory can also be applied to create future experiences through imagination, not through the senses. Our senses are only servants of making the imagination recognizable. This is where I make a distinction between visualization and imagination: whereas visualization is recalling past experiences and events, imagination is envisioning events and creating experiences that have never occurred previously. This is why visualization and imagination are inclusive of each other, but not synonymous.

Consciousness does not separate, but rather distinguishes, the living present from the imagined future; the former is visualization and "the temporal ground on which my present perception develops;" the latter is imagination and "posited for itself but as that which is not yet" (Sartre, 1948, p. 264). The real and the imaginary paradoxically intertwine by navigation through diaphanous space and polychronic time (Seif, 2016a). In order to catch the inaudible and the invisible we must rely on a different structure, that which I have called elsewhere "notating imagination"1 (Seif, 1999; Seif, 2009). To rely on memory as a "phantasmagorical" phenomenon (Bergson, 1912), and to engage in the notating process, we must practice imagination and visualization: imagining that which is yet-to-be and visualizing that which is imagined as a real living experience. This is what Vico meant by fantasia as a distinctive feature of the human mind, enabling us to form mental images from memories and experiences and playing with sign relations in a new way by crossing boundaries through them.

\section{Persevering through Paradoxes of the Real and the Imaginary}

Since reality is not merely the subjective conditions of physical existence, nor is it only those conditions independent of whether we are aware of them or not, experiencing reality is based on the real and the imaginary. Experiencing reality begins first when objects come into existence through the awareness of the human mind (Deely, 2004), and also when, through the action of signs, the imaginary object becomes the real thing. Without the action of signs, there could be no objects, and without objects there could be no awareness of things in the world, and without design, neither an object nor a thing can manifest in the world. 
Paradoxically, the imaginary transcends the real in order to reconstruct the very existence of reality. This paradoxical statement seems to contradict common sense. But although common sense performs reasonably well in some circumstances, its very nature of being common is, ironically, itself not common sense (Sorensen, 2003). To persevere through this paradox, we need to shift from common sense to uncommon sense, so as to overcome the erroneous, socially constructed boundaries between the real and the imaginary.

Persevering through the paradox of the real and the imaginary requires our consciousness to be momentarily separated from being-in-the-world, by navigating through diaphanous space and polychronic time, in order to be able to imagine. And it is through this navigation that consciousness is able to momentarily withdraw from the world, surpassing the real in order to make the imaginal world real again. The paradox of withdrawing-from, yet being-in, the world is the necessary condition for making the imaginary real.

Imagining the future by design depends on our perseverance through this paradox of the real and the imaginary, where design intention does not lead to a predetermined destination or arrive at a specific solution, but is open to unexpected emergent outcomes (Seif, 2014; 2015), and where the action of signs does not distinguish between the real and the imaginary. Persevering through this paradox assists us to better understand the relation between intentionality and playfulness. While the former makes it possible for us to perceive the world and to make meaning of it, the latter is a moderate indulgence of play that is amusing and recreational.

This play of musement transcends search and research into design inquiry, which does not proceed with preconceived ideas. ${ }^{2}$ Search and research have been associated with the scientific method, which is derived predominantly from inductive and deductive reasoning and seeks accurate understanding through the establishment of facts. Traditional search and research are triggered by needs and necessity, which may motivate a hypothesis directed toward a predetermined result or specific answer that, in turn, gives a biased view of reality (Buchanan, 1995; Cross, 1995).

But design inquiry is motivated by abduction, desire, and a sense of wonderment; and teleologically oriented toward unexpected and emergent outcomes. While both search and research are positioned mostly on a problem-solving trajectory and projection to maintain what has been in existence, design inquiry is oriented toward the emergence of that which is yet-to-come (Seif, 2016b). Design inquiry utilizes Peirce's abduction, which is achieved emotionally by inferring something from the conjunction of past and present realities, and goes beyond past memory into future memory. While present reality is constructed by past memory, it can also be transformed by future memory, which is the upshot of the playfulness of the muse, the sense of wonder of navigating through space-free and time-free reality.

\section{The Muse of Phantasmagorical Memory: Playing with Boundaries}

"Play, we all know, is a lively exercise of one's powers," where musement is a moderate indulgence of play that "has no purpose, unless recreation" (CP 6.458). Developing Peirce's concept of the play of musement, Thomas A. Sebeok (1981) also conjectures the possible real and imaginary worlds in the interplay among human beings and more-than-humans. In this sense, play of musement incites human beings, as "infinite-game players" (Carse, 1986) to continue playing with boundaries, not within the established boundary of known reality. In this way, human beings are in a position not only to question reality, but also to work for a better world (Petrilli, 2016) by imagining a desired future.

\footnotetext{
2 Unlike the autonomous disciplines of the humanities and sciences, which rely mostly on systematic investigation of search and research and follow defined processes that are generally repeatable and result in predictable products, Design and semiotics utilize systemic inquiry, which is wholistic and integrative and can lead to unexpected outcomes. Design inquiry requires that facts and truths be considered as operational, indeterminate, and representative. Manipulation of these facts and truths, and toying with everything that is thought to be completely determined, have always involved a tentative withdrawal from absolute reality and the linear projection from the known past and present to the unknown future.
} 
Once again, memories of the past are the familiar path to predicting and forecasting the future. While these memories generally provide explanations of historical events and physical conditions, they are not necessarily a meaningful way to imagine a preferred future. The future cannot be achieved through forecasting, predication, or science fiction, but only through the muse of phantasmagorical memory. Memory is commonly thought of as a recollection of past experiences and events. It is the capacity of the mind to store and retrieve experiences through images from the past. In ancient time, devoid of printing, the art of memory depended on sensory memorization of places and images (Yates, 1966). But memory as a phantasmagorical phenomenon does not separate past memory from future memory.

Memory of the past leads to repetition of that which has been in existence and, therefore, maintains the status quo. Conversely, memory of the future opens an infinite spectrum of new possibilities, leading to a breakthrough for a meaningful future. Although Immanuel Kant treats the image of the past, present, and future distinctly, there is a synoptic formation that incorporates all three. It has been suggested that when we replicate past representations or anticipate future representations we are retrieving images that have been derived from our experiences and stored in our imagination (Makkreel, 1990). This is not quite so. Although images are derived generally from our experience and imagination, images are retrieved from past memory through visualization, but are captured by future memory through imagination.

The nagging questions then become, how do we find a way throughout this web of memories? And how do we differentiate between recalling past memories and imagining future memories? Since imagination reveals the idea of the whole, it refines and crystallizes what is lacking in past memories and present experiences. To remember the future is to reframe our relationship with how we experience time. Although linear time is a concept we have accepted, it is not as real as it may appear; considering Einstein's work, time is a relative reality. Why is this important? What is the connection between perceived reality and future memory? Human beings perceived the world as a three-dimensional space modulated by the passage of time. In this sense, spatiality and temporality in human experience are merely ordering systems upon which all objects in the world can be perceived as real. The so-called 'present time' is an illusion; so is the notion of 'here'. Paradoxically, while the expression "here and now" is cognitively real, it is fundamentally untrue. Although space and time are held to be empirically real, they are not true. What is real is not always true. Neither are space nor time absolute notions (Seif, 2016c).

Interestingly, memory is from the Latin word memoria, which literally means "mindful remembering." One can make a case that to remember mindfully is to seek meaningful change, a transformation process, and this is, I believe, the core purpose of future memory. A meaningful approach to envision the future demands a shift from the gravity of the presence to the weightless, dreamlike state of an imaginable future. This transformation goes beyond the need for speed and accuracy into a transparent perception and meaning making. We need this transformational process to move beyond the perceived limitations and illusionary barriers of space and time that we have often unjustifiably constructed for ourselves.

Specifically, future memory is practiced as if one imagines being in a distant future and then reminiscing about the memory of the past, which is really a memory of the future. This may seem an oxymoron, but contradictions of the oxymoron are the true wisdom within all paradoxes. Indeed, it is possible to remember things that are yet-to-be. Ironically, strange as it may seem, it is easy to trick the mind to imagine future events and experiences, recalling and reminiscing about them as they were in the past. ${ }^{3}$

\footnotetext{
3 I use the idea of future memory with my graduate students and organizations to free their minds from the gravity of the present and to help them disregard, even temporarily, the limitations of current conditions. Many students and managers seem to have discovered the cognitive leap that is essential for creating a sustainable and meaningful future.
} 
Phantasmagorical memory provides a cognitive leap that is essential for creating sustainable social change and environmental renewal. The content of this memory becomes the apparatus for imaginative interpretation that leads to intentional change. The challenge now is how to communicate or represent the complex and rich images of a life-to-come. This is where the concept of notating imagination (Seif, 1999) becomes dexterous and transcends linear projection to the future, whether in the form of utopian optimism or dystopian pessimism.

\section{Phantasmagorical Memory and Notating Imagination}

The idea of notating imagination is certainly an age-old phenomenon; it has its deep roots in primordial time. For instance, pre-historic cave paintings were not intended to serve as records of the past, as has commonly been believed. Rather, these paintings were graphic representations of magical thinking and enactment intended to create new realities and therefore influence the future. How do we capture and represent phantasmagorical memory? It is through notating imagination that we can communicate the mental images and visual thinking of time to come, with a potential for converting conceptualization into actualization, abstraction into concreteness. By integrating factual information and imaginative interpretations, the content of phantasmagorical memory can be represented and communicated both to oneself and to others.

As a robust means of intercommunicative signs, notating imagination is a graphic representation of phantasmagorical memory, which hardly can be attained and communicated in any other way. Being at the core of meaningful change, notating imaginative memory is an essential practice for externalizing thoughts and reflecting on that which is yet-to-be. The complexity of one's inner deliberation demands a different language for communicating and developing the vitality of phantasmagorical memory. In this sense, it is important to recognize that imaginative thinking far exceeds the natural languages that utopian text relies upon.

It is not unusual for natural language to monopolize the mind to a degree that thought is rendered a slave to words and imagination is trapped in sequential and analytical boxes (Koestler, 1964). That is why we need to use a robust representation capable of sustaining and communicating the cognitive shift triggered by phantasmagorical memory. However, notating imagination is not a replacement for written or spoken languages; rather, its inclusive quality and capacity to superimpose multiple images expands our cognitive understanding and visceral awareness.

Natural language is not enough for imagining a desired future. Ironically, while language makes it possible for us to think abstractly, we seem to abandon the use of images. For imagination involves more than logical, linear operations; it depends on the acquisition, interpretation, and manipulation of images and nonverbal codes. Imagination does not fit neatly into the mainstream, conservative thinking. Words are effective systems for describing life experiences and cognitive events, but they are not the experiences or events themselves (Koestler, 1964). Even with its magnificence and robustness, language is not indispensable to our thought. Language is helpful to abstract thinking; however, thinking is not in words (Seif, 2009). This is the paradox of the splendor and tyranny of language.

Abstractions and concreteness are the properties of all physical and mental things. Being not mutually exclusive, abstraction and concreteness are connected perceptually through the notion of generalization (Arnheim, 1969). Because abstraction is the human brain's highest function, it is an indispensable attribute of notating imagination. When we think of concepts such as freedom, justice, or peace, we are not thinking in physical images; rather we are thinking abstractly. And when we make imaginative connections among freedom, justice, and peace we are also thinking abstractly, but metaphorically. Only when we reflect, muse, ${ }^{4}$ and play with boundaries do we revert to images,

\footnotetext{
4 There is a strong connection between the notion of "memory" and the term "muse." In ancient Greek mythology, the goddess of the Titanic world Mnemosyne (memory or recollection) is mother of the Muses (Yates 1966). Essentially, Mnemosyne is the memory of the "great deed," the "founding of a new world order," and inspiration that "emanates from the beauty and harmony of the world." Etymologically, the word "muse," from mousa, means "the ponderess," or "dreamer" to muse is "to ponder, to dream," or "reflect upon" (Gebser 1949: 317-318). Hence, memory (Mnemosyne) is the mother of all the arts and sciences of human creation
} 
metaphors, and signs to trigger our imagination. The British philosopher Owen Barfield makes a good point for considering imagination as a whole new way of using language itself: One of the things that images, metaphors, and symbols do is to develop and strengthen our faculty of imagination. For without that we soon find that we can make nothing of them. It could be that, in a time still to come, this faculty, once it has been so developed, will be valued, not primarily as an end in itself, but rather as a preliminary training in a whole new way of using language - a way that will be neither vague and inaccurate on the one hand nor rigid and definition-ridden on the other. Language so used would be the true utterance of "double vision" inasmuch as it would embody a simultaneous, and yet not an intermeddling, awareness and acceptance of both the two opposite sides of the threshold (1977, p. 129).

Language as semiology can be located within the larger scope of semiotics. Under this larger scope, there are three major semiotic systems: linguistics, kinesics, and objects. Certainly, language is only one of three major systems of signification in almost any sociocultural setting. While language is one of our main systems of communication and signification, it is not our highest ability. A considerable portion of our mental activity is of a nonverbal character (Seif, 1999); we often use gestures and facial expressions in our communication, which indicates our disparate efforts to overcome the limitations of language.

According to Charles S. Peirce, semiotic signs in relationship to their objects are of three types: iconic, indexical, and symbolic. What concerns us here is the symbolic sign. A symbolic sign relates to its object only by an association of an idea, which has to be created and learned within a social or cultural context. Convention sets the random link between a symbolic sign and its object. In this type, signs and their objects are related by virtue of an agreement and convention, not by virtue of any quality intrinsic to either the object or its sign. Although there is an inclusion of the three sign types in any given representation, words in all natural-languages are predominantly symbolic signs. This symbolic representation of alphabets, of course, is different from Egyptian hieroglyphic systems of writing, Native American pictographs, and Chinese logograms.

These ancient systems of writing were in fact shorthand signs or notae (Yates, 1966). Notae may also be linked to the Latin word notitia (Hillman, 1992), in which the original meaning has much to do with the human capacity to conceptualize through the attentive noticing on which imagination depends. The very nature of noticing may convey the essence of notating mental images. In a general sense, notations are analogous to words in language and similar to writing. For those "who know the letters of the alphabet can write down what is dictated to them and read out what they have written. Likewise those who have learned mnemonics can set in places what they have heard and deliver it from memory" (Yates, 1966, p. 6-7). The process and skills of notating phantasmagorical memory can be learned.

To imagine is to make an image. The act of making an image is a "philomorphic", or form-loving, act (Grudin, 1990). The act of making an image is really a lovemaking act. The act of making an image is giving life to form or "ensouling" (Hillman, 1992). In an Aristotelian sense, the soul "never thinks without a mental picture". The notion of mental imagery has been one of the main philosophical discourses since Aristotle's De Anima. More recently, the significant role of images in thinking has been emphasized by many artists as well as scientists. For instance, describing his thinking method, Albert Einstein once wrote: The words or the language, as they are written or spoken, do not seem to play any role in my mechanism of thought. The physical entities which seem to serve as elements in thought are certain signs and more or less clear images which can be 'voluntarily' reproduced and combined (Koestler, 1964, p. 171).

While specialized jargon and even linguistic obscurity have contributed to the advancement of human knowledge, they have rendered professional domains and fields more isolated. Consequently, each domain is becoming increasingly specialized in its vocabulary and the conceptual organization of its system. And while the tendency toward specialization has made professional mastery and 
precision possible, it has also created rigid boundaries accessible only to those qualified practitioners who are well trained to play within those established boundaries. Creating a meaningful future demands a transdisciplinary approach, capable of crossing conventional boundaries and fields (Seif, 2015). Notating phantasmagorical memory is a means of communicating beyond cultural differences, disciplines of humanities and sciences, and the boundary of time into future generations, and perhaps extraterrestrial beings or other species. This process has far-reaching social and cultural implications for understanding the nature of reality and imagining the future.

\section{Conclusion: Imagining the Future in the Transmodern World}

We seem to be experiencing a major shift in our perceptions and experiences of reality, which once were seen as absolute. Yet while the shift is major, it is very subtle and sometimes slow. Such a subtle, slow shift also seems to have taken place from modernity to postmodernity. Modernity represents a linear trajectory that starts with colonialism and ends with postmodernity, which ironically has emanated as an eclipse of modernity by ignoring the historical success of its antecedents, turning the past into a storehouse of images and pastiches for self-indulgent imitation and simulacra of utopian optimism. Postmodernism seems to capitalize on modernity's slogan "time is money." And in doing so, postmodernists make the acceleration of time an important characteristic of absolute economic reality: going faster and acquiring material, physical things are considered winning the game of forecasting and projection. It is clear that postmodernity has been superseded by transmodernity (Dussel, 1985).

The core value of transmodernity, which embodies many integrative qualities and undissolved differences, emphasizes transparency between pre-modern, modern, and postmodern realities. Not only does transmodernity discard modernity's insistence on autonomy and absoluteness, it also transcends modernism and postmodernity's inclination toward dualistic rationality and an either-or position (Seif, 2008; Seif, 2015).

A desired future in the transmodern world can be created through phantasmagorical memory and communicated by the notating and scoring process. Such future possibilities are emergent outcomes of the design process that teleologically reveals unlimited options. Notating the imagination of phantasmagorical memory transforms the status quo into a visceral experience of a desirable future in our transmodern world. This is the way we can transform the present reality into a desired future reality. Without such memory, it would be difficult to avoid the despair about the status quo and to go beyond utopianism and dystopianism.

To imagine the future is to transform absoluteness and to participate in a process that seeks meaningful change. Imagining a desired future in the transmodern world is essential for rejuvenating cultural practices and renewing natural environments. And notating imagination - the unseen forces behind physical manifestations - reveals an integrated consciousness that highlights the reciprocal relationship between cultural ethos and environmental ethics.

Transmodernity offers circumstances par excellence for making a shift from our outdated habits and blind beliefs into a transparent imaginative consciousness. Such consciousness is capable not only of seeing through modernity, postmodernity, and transmodernity, but also of integrating the real and the imaginary in order to intentionally direct us toward ways of thinking and doing appropriate for creating a meaningful future. The heart of the matter is not that we need to cope with a complex, changing world by forecasting and projection; rather, we need to acquire the design thinking that allows us to learn how to navigate through the transmodern world creatively and resiliently. This is the way towards envisioning a desired future that transcends speculative utopian optimism and science fiction pessimism.

\section{REFERENCES}

Arnheim, Rudolf (1969). Visual Thinking. Berkeley, CA: University of California Press. Barfield, Owen (1977). The Rediscovery of Meaning: and Other Essays. Middletown, CT: Wesleyan University Press. 
Bergson, Henri (1912). Matter and Memory, trans. Nancy Margaret Paul and W. Scott Palmer. New York, NY: The Macmillan Company.

Buchanan, Richard (1995). Wicked Problems in Design Thinking. In The Idea of Design: A Design Issues Reader (Ed.). Victor Margolin and Richard Buchanan. Cambridge, MA: The MIT Press.

Carse, James P. (1986). Finite and Infinite Games: A Vision of Life as Play and Possibility. New York, NY: The Free Press.

Cross, Nigel (1995). Discovering Design Ability. In Discovering Design: Explorations in Design Studies, ed. Richard Buchanan and Victor Margolin. Chicago, IL: University of Chicago Press.

Cross, Nigel (2011). Design Thinking: Understanding How Designers Think and Work. Oxford, UK: Berg/Bloomsbury.

Danesi, Marcel (2007). The Quest for Meaning: A Guide to Semiotic Theory and Practice, Toronto, Canada: University of Toronto Press.

Deely, John N. (2004). Why Semiotics? New York, NY: Legas.

Derrida, Jacques (2007). A Certain Impossible Possibility of Saying the Event, Critical Inquiry, 33, (2 (Winter 2007)), 441-461.

Dussel, Enrique (1985). Philosophy of Liberation, trans. Aquilina Martinez and Christine Morkovsky. New York, NY: Orbis Books, 2003.

Gebser, Jean (1949). The Ever-Present Origin, trans. Noel Barstad and Algis Mickunas, Athens, OH: Ohio University Press, 1985.

Grudin, Robert (1990). The Grace of Great Things: Creativity and Innovation. New York, NY: Ticknor \& Fields.

Hillman, James (1992). The Thought of the Heart and the Soul of the World. Woodstock, CT: Spring Publications.

Huxley, Aldous (1932). Brave New World. New York, NY: Harper \& Brothers Publishers.

Jameson, Fredric (2005). Archaeologies of the Future: The Desire Called Utopia and Other Science Fictions. New York, NY: Verso.

Koestler, Arthur (1964). The Act of Creation. London, UK: Penguin Books Ltd.

Koyaanisqatsi: Life Out of Balance, 1982 film. Directed by Godfrey Reggio.

Leslie, John (1996). The End of the World: The Science and Ethics of Human Extinction. London, UK: Routledge.

Makkreel, Rudolf A. (1990). Imagination and Interpretation in Kant: The Hermeneutical Import of the Critique of Judgment. Chicago, IL: The University of Chicago Press.

Peirce, Charles Sanders (1839-1914). The Collected Papers of Charles S. Peirce, Vols. I-VI, ed. Charles Hartshorne and Paul Weiss, Cambridge, MA: Harvard University Press. Vols. VII-VIII, ed. Arthur W. Burks (same publisher, 1958). References from this source are abbreviated as CP followed by numbers that refer to the volume and paragraph with a period in between.

Petrilli, Susan (2016). The Global World and its Manifold Faces: Otherness as the Basis of Communication. Bern, Switzerland: Peter Lang AG.

Propp, Vladimir (1928). Morphology of the Folktale, trans. Laurence Scott. Austin, TX: University of Texas Press.

Rittel, Horst \& Melvyn M. Webber (1973). Dilemmas in a General Theory of Planning, Policy Sciences, 4 (2), 155-169.

Sartre, Jean-Paul (1948). The Psychology of Imagination, trans. Jonathan Webber, New York, NY: Philosophical Library.

Sebeok, Thomas A. (1981). The Play of Musement, Bloomington, IN: Indiana University Press.

Seif, Farouk Y. (1999). Sign Processes and Notational Design: Demystifying Design Thinking and its Representation, Sign Processes in Complex Systems, Proceedings of the 7th International Congress of the International Association for Semiotic Studies-Association Internationale de Sŭmiotique, 7-11 October 1999, ed. Walter Schmitz, Dresden, Germany: Technische Universitдt Dresden. 
Seif, Farouk Y. (2005). Social Change in the 'Aperspectival World': The Paradox of Social Reproduction and Cultural Innovation. TRANS, no. 16/2005. http://www.inst.at/trans/ 16Nr/01_2/seif16.htm.

Seif, Farouk Y. (2008). At Home with Transmodernity: Reconstructing Cultural Identity in a Globalizing World. In Transmodernity: Managing Global Communication, ed. Doina Cmesiu, Proceedings of the 2nd ROASS Conference, Slavic-Moldova, Romania, 23-26 October 2008; Васги, Romania: Alma Mater Publishing House, 2009, 248-256.

Seif, Farouk Y. (2009). Communication in the Age of Great Turning: Understanding the Role of Analog and Digital Modes in Liberating Imagination. In Communication: Understanding / Misunderstanding. Proceedings of the 9th World Congress of the IASS/AIS, Helsinki-Imatra, Finland, 11-17 June 2007, ed. Eero Tarasti. Imatra, Finland: The International Semiotics Institute.

Seif, Farouk Y. (2014). Paradoxes and Perseverance: Designing Through Antinomies of Life, Semiotics 2014: The Semiotics of Paradox. New York, NY: Legas. 2015, 135-160.

Seif, Farouk Y. (2015). Reality Beyond Humanities-Science Schism: Revealing the Mutuality of Design and Semiotics, The American Journal of Semiotics, 31 (3-4), 311-336.

Seif, Farouk Y. (2016a). Resilience and Chrysalis Reality: Navigating Through Diaphanous Space and Polychronic Time, Signs of the Times, Selected proceedings from the 10th International Conference of the Hellenic Semiotics Society, 2013, ed. Eleftheria Deltsou \& Maria Papadopoulou, 52-66.

Seif, Farouk Y. (2016b). Can Design Inquiry Advance Edusemiotics? Rethinking Factual Information and Imaginative Interpretation, Semiotica: Journal of the International Association for Semiotic Studies, Special Issue on Edusemiotics, De Gruyter Online, DOI 10.1515/sem-2016-0122.

Seif, Farouk Y. (2016c). What is Real is Not Always True! Reconstructing Reality in a Transmodern World. In Is It Real? Structuring Reality by Means of Signs, ed. Zeynep Onur, et al. Cambridge, MA: Cambridge Scholarship Publications, 46-65.

Sorensen, Roy (2003). A Brief History of the Paradox: Philosophy and the Labyrinths of the Mind. New York, NY: Oxford University Press.

Vico, Giambattista (1688-1744). The New Science of Giambattista Vico, trans. Thomas G. Bergin and Max H. Fisch. Ithaca, NY: Cornell University Press, 1948.

Yates, Frances A. (1966). The Art of Memory. Chicago, IL: The University of Chicago Press. 